\title{
Istraživački pristupi i metodološki okviri u istraživanjima budućih učitelja
}

Snježana Dubovicki*

sdubovicki@gmail.com

Vesnica Mlinarevićc*

vmlinarevic@foozos.hr

Tena Velki

tvelki@foozos.hr https://doi.org/10.31192/np.16.3.11

UDK: $377.8-057.875$

303.42:378

Prethodno priopćenje / Preliminary kommunication Primljeno: 18. lipnja 2018. Prihvaćeno: 15. rujna 2018.

U novije vrijeme u društvenim znanostima, a posebno u pedagogiji, različita istraživačka iskustva podrazumijevaju različite istraživačke stilove i filozofske pristupe koje je potrebno poznavati prije provođenja istraživanja. U radu se daje pregled različitih istraživačkih pristupa $i$ znanstvenih paradigmi u okviru kojih je moguće kreirati i usmjeriti osobni istraživački projekt (istraživanje). Cilj i svrha rada je istražiti i upoznati različite istraživačke pristupe i metodološke okvire koji se ogledaju u zastupljenosti stanovitih znanstvenih paradigmi, primjeni kvalitativne i kvantitativne metodologije te različitih istraživačkih tehnika kojima se u svojim istraživanjima koriste budući učitelji. Iz navedenih je razloga istraženo 159 diplomskih radova studenata Učiteljskoga studija Fakulteta za odgojne i obrazovne znanosti Sveučilišta u Osijeku koji su javno obranjeni od siječnja 2015. do prosinca 2017. godine. Uvidom u diplomske radove studenata dobiveni su sljedeći rezultati: od ukupnoga broja diplomskih radova (159), njih 132 (83\%) ima istraživanje. Nadalje, znanstveno područje koje je najzastupljenije u istraživanjima su društvene znanosti (36,47 \%), a unutar njih polje pedagogije (46,55 \%). Prema vrsti istraživanja dominiraju empirijska, temeljna, transverzalna i istraživanja sadašnjosti. Od svih istraženih znanstvenih paradigmi, najzastupljenija je pozitivistička (60,6\%), a potom konstruktivistička (17,43\%) i postpozitivistička (15,91 \%) paradigma. Dominiraju primijenjena istraživanja (78 \%), dok su razvojna istraživanja (5 \%) još uvijek nedovoljno zastupljena i prihvaćeno kod studenata.

Ključne riječi: diplomski radovi, studenti učiteljskoga studija, vrste istraživanja, znanstvene paradigme.

* Doc. dr. sc. Snježana Dubovicki, Fakultet za odgojne i obrazovne znanosti, Sveučilište Josipa Jurja Strossmayera u Osijeku, Cara Hadrijana 10, HR-31000 Osijek.

** Prof. dr. sc. Vesnica Mlinarević, Fakultet za odgojne i obrazovne znanosti, Sveučilište Josipa Jurja Strossmayera u Osijeku, Cara Hadrijana 10, HR-31000 Osijek.

***: Izv. prof. dr. sc. Tena Velki, Fakultet za odgojne i obrazovne znanosti, Sveučilište Josipa Jurja Strossmayera u Osijeku, Cara Hadrijana 10, HR-31000 Osijek. 


\section{Uvod}

Svako znanstveno istraživanje polazi od nekog znanstvenoga pristupa $u$ kojemu je ugrađen stanovit opći filozofski i pojmovni okvir. Taj se okvir naziva znanstvenom paradigmom. Paradigma se može definirati kao opći pogled na svijet; skup ontoloških, epistemoloških i metodoloških pretpostavki prema kojima se istraživač rukovodi $\mathrm{u}$ istraživanju. ${ }^{1}$ Ontološke pretpostavke odnose se na (ne)postojanje jedne jedinstvene objektivne realnosti. Epistemološke pretpostavke podrazumijevaju shvaćanja prirode znanja i mogućnosti dolaženja do znanja, a metodološke pretpostavke proizlaze iz dviju prethodno navedenih i tiču se poželjnih načina istraživanja onoga što se može istražiti. Osim navedena tri osnovna područja, navodi se još i aksiološko područje u kojemu se postavlja pitanje o ulozi vrijednosti $u$ istraživanju ${ }^{2}$ te retoričko područje koje se bavi pitanjem terminologije i jezičnoga stila koji istraživači koriste. ${ }^{3}$ Odabir neke paradigme odredit će sve aspekte procesa istraživanja, od problema koji će biti istraživani do metoda njihova istraživanja.

Pored paradigme razumijevanja i paradigme pojašnjavanja, ${ }^{4}$ Bognar ${ }^{5}$ obrazlaže osnovne značajke pet znanstvenih paradigmi apelirajući na prihvaćanje znanstvenog pluralizma koji bi mogao doprinijeti demokratizaciji, raznolikosti i afirmaciji stvaralaštva u procesu odgoja i obrazovanja. Do pomaka paradigmi došlo je ponajviše stoga što se unutar paradigme razumijevanja i paradigme pojašnjavanja nisu isticale posebnosti i filozofija pojedinih istraživačkih pristupa i instrumenata istraživanja. Imajući na umu nove činjenice i pretpostavke s kojima se susrećemo $u$ istraživanjima, potrebno je transformirati teorije i pravila te ostvariti nove iskorake koje nam mogu pomoći u stvaranju nove paradigme.

\section{Znanstvene paradigme u istraživanjima odgoja i obrazovanja}

Polazeći od pretpostavke da je znanstvena paradigma jedna od najboljih pokazatelja nekog metodološkog pristupa (jer iz nje možemo iščitati postojanje stanovitih istraživačkih alata te prevlast kvalitativne i/ili kvantitativne meto-

${ }^{1}$ Usp. W. FILSTEAD, Qualitative methods. A needed perspective in evaluation research, u: T. Cook, C. Reichardt (ur.), Qualitative and Quantitative Methods in Evaluation Research, Newbury Park, CA, Sage, 1979, 33-48, 33.

${ }^{2}$ Usp. J. HERON, P. REASON, A participatory inquiry paradigm, Qualitative Inquiry, 3 (1997) 3, 274-294, 276.

${ }^{3}$ Usp. J. W. CRESWELL, Qualitative inquiry and research design. Choosing among five approaches, London, New Delhi, SAGE Publications, 2007, 35-41.

${ }^{4}$ Usp. V. MUŽIĆ, Uvod u metodologiju istraživanja odgoja i obrazovanja, Zagreb, Educa, 2004, 19.

${ }^{5}$ Usp. B. BOGNAR, Pedagogija na putu prema pluralizmu znanstvenih paradigmi i stvaralaštvu, u: N. HRVATIĆ, A. KLAPAN (ur.), Pedagogija i kultura, Zagreb, Hrvatsko pedagogijsko društvo, 2012, 100-110, 100. 
dologije), u daljnjem tekstu dajemo kratak pregled znanstvenih paradigmi i njihovih osnovnih značajki da bismo lakše mogli pratiti rezultate istraživanja.

U istraživanjima odgoja i obrazovanja postoje dvije znanstvene paradigme: paradigma razumijevanja i paradigma pojašnjavanja (ili tumačenja). ${ }^{6}$ Teži se prema njihovoj sintezi, odnosno, imajući na umu pozitivne aspekte i jedne i druge paradigme, tijekom procesa istraživanja treba postići višu razinu rezultata istraživanja triangulacijom. ${ }^{7}$

Polazište paradigme razumijevanja usmjereno je na produbljeno shvaćanje istraživanih pojava s težnjom prema subjektivnosti. To omogućuje potpuniju i bogatiju interpretaciju pojave koja se temelji na bogatim i valjanim informacijama. Analiza podataka u paradigmi razumijevanja temelji se na kvalitativnim aspektima. To znači da se pri analizi podataka pozornost usmjerava na opisna, nebrojčana, atributivna obilježja pojava (spol, nastavni predmet, razina završenoga stupnja obrazovanja). Metodološki aspekt ove paradigme je fenomenološki, uz postupak hermeneutičke analize. Fenomenološki je postupak usmjeren spoznavanju same pojave koja polazi od intuitivnog spoznavanja ostvarujući fenomenološku redukciju. Ta redukcija isključuje stav istraživača, tj. intuicija je okrenuta prema objektu istraživanja, sva prethodna teorijska nadogradnja promatranog fenomena i svaku tradiciju u svezi s poimanjem fenomena. Svrha paradigme razumijevanje je idiografska, ${ }^{8} \mathrm{tj}$. ona koja nastoji pomoći pojedincu uz primjenu znanstvenoga pristupa. Prema načinu prikupljanja podataka iz odgojno-obrazovne empirije, paradigma razumijevanja teži za što prirodnijim, naturalističkim, neoptruzivnim promatranjem pojava u kojemu istraživač nastoji biti što bliži izvoru podataka promatrajući iz perspektive »insajdera«. Što se tiče odnosa između procesa i rezultata aktivnosti, tj. odgoja i obrazovanja, paradigma je razumijevanja usmjerena na proces i dinamičku realnost. Naklonjena je holističnosti, tj. promatranju neke pojave u njezinoj cjelovitosti.

Težište paradigme pojašnjavanja je u uspostavljanju uzročno-posljedičnih veza te ju zbog toga nazivamo i kauzalnom paradigmom. Podaci prikupljeni takvom paradigmom moraju biti pouzdani i ponovljivi. Iz toga proizlazi objektivnost pristupa ove paradigme. Pri analizi podataka pozornost je usmjerena na brojčana obilježja pojava (odnos broja muških i ženskih nastavnika, broj sati pojedinog nastavnoga predmeta, broj učenika u razredu) koje zahtijevaju statističku obradu. Metodološki okvir ove paradigme podrazumijeva empirijsko-analitičke postupke kojima se utvrđuju stvarne (tj. pozitivno postojeće) činjenice. Svrha je istraživanja paradigme pojašnjavanja nomotetička, ${ }^{9}$ odnosno stvaranje znanstvenoga zakona ili potvrđivanje znanstvene pretpostavke koja utvrđuje stalne odnose između promatranih pojava. Težnje su ove paradi-

\footnotetext{
${ }^{6}$ Usp. Mužić, nav. dj., 17.

${ }^{7}$ Naziv triangulacija potječe iz zemljomjerstva, a čiji je osnovni smisao da se pojava može točnije uočiti kada se promatra s različitih stajališta (isto, 20).

${ }^{8}$ Od grč. idios = pojedinac .

9 Od grč. nomos = zakon.
} 
gme usmjerene prema što većoj kontroli situacije u kojoj se prikupljaju podaci. Istraživač je subjektivno udaljen od izvora podataka i gleda iz perspektive »outsajdera ${ }^{10}{ }^{10}$ Paradigma pojašnjavanja je usmjerena na rezultat istraživanja, a ne na njen proces, partikularistična je i daje prednost promatranju pojedinačnih aspekata pojave.

U okviru paradigme razumijevanja i paradigme pojašnjavanja posebno se ne ističu posebnosti i filozofija pojedinih istraživačkih pristupa i instrumenata istraživanja (kojih je u novije vrijeme sve više, a nastaju sukladno novim dostignućima i izazovima pojedinih znanosti) pa proizlazi potreba za svojevrsnom lepezom znanstveno-istraživačkih paradigmi. Kao odgovor na nastalu problematiku u nastavku donosimo osnovne značajke pet znanstvenih paradigmi koje smatramo važnima posebno u pedagoškim istraživanjima: pozitivistička paradigma, postpozitivistička paradigma, konstruktivistička paradigma, kritička teorija i sudjelujuća paradigma. ${ }^{11}$

Polazište pozitivističke paradigme je u postojanosti realnosti izvan čovjeka koja je podčinjena nepromjenjivim prirodnim ili društvenim zakonitostima. Ontološko područje pozitivizma postavlja specifično vjerovanje u mogućnost točne spoznaje prirodnih i društvenih fenomena pa se takav pristup naziva i naivni realizam. Epistemologija pozitivizma nastoji distancirati istraživače od predmeta svoga istraživanja, odnosno nastoji izbjeći moguć subjektivan utjecaj na rezultate istraživanja. ${ }^{12}$ Svrha takvog istraživanja jest objektivna spoznaja stvarnosti na temelju empirijski prikupljenih podataka. Metodologija pozitivističkog pristupa uključuje metode koje omogućuju precizno mjerenje, kvantifikaciju, manipulaciju i kontrolu varijabli te testiranje hipoteza, a pri tome se koriste eksperimenti, kvazi-eksperimenti, korelacijska i anketna istraživanja. Podrazumijeva se primjena sofisticiranih statističkih postupaka pri obradi prikupljenih podataka jer se istraživanja uglavnom provode na reprezentativnom uzorku. ${ }^{13}$

Postpozitivistička paradigma nastaje u okvirima kritičkog realizma. Zastupa stajalište o postojanju objektivne realnosti čija je spoznaja uvijek nesavršena i djelomična, stoga su takvi istraživači samokritični prema rezultatima svojih istraživanja. Epistemološke pretpostavke postpozitivizma navode da njihovi istraživači rezultate znanstvenih istraživanja smatraju tek dokazanim tvrdnjama, a su utvrđene pravilnosti, a ne univerzalne zakonitosti. ${ }^{14}$ Oni i dalje zagovaraju objektivnost kao znanstveni ideal, ali pri tome ostavljaju prostor za stalnu provjeru dosegnutih teorijskih spoznaja procesom falsifikacije. Falsifikacija neke teorije podrazumijeva stvaranje nove teorije koja primjerenije

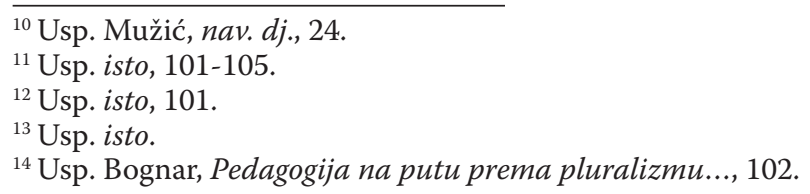


i potpunije objašnjava prirodne ili društvene fenomene. ${ }^{15}$ Metodološki aspekt postpozitivističkog pristupa sugerira korištenje kritičkog multiplizma koji je oblik metodološkog pluralizma kojim se nastoje smanjiti pogreške prilikom izbora i korištenja pojedinih metodoloških i teorijskih pristupa. ${ }^{16}$

Konstruktivistička paradigma obilježava otklon prema ontološkoj pretpostavci o postojanju samo jedne jedinstvene realnosti. S obzirom na to da u konstruktivistički orijentiranim istraživanjima nastaje više različitih interpretacija i da ne postoji jednoznačna istina, to znači da je u ontološkom smislu ta paradigma relativistička. ${ }^{17}$ Epistemološki aspekt konstruktivizma navodi da inzistiranje na objektivnosti nema previše smisla. Istraživač i predmet istraživanja su u međusobnoj interakciji i utječu jedan na drugoga iz čega proizlaze rezultati istraživanja. Metodologija je hermeneutička (interpretativna), dijalektička i naturalistička. Najvažniji je instrument prikupljanja podataka istraživač koji nastoji razumjeti i interpretirati individualne konstrukcije sudionika istraživanja. Oslanja se na intuitivno i teorijsko znanje te metode kojima se prikupljaju i analiziraju uglavnom kvalitativni podaci, kao što su analiza dokumentacije, intervjuiranje i promatranje sudionika istraživanja. ${ }^{18}$

Kritička teorija je široko zastupljena paradigma u kvalitativnim pedagoškim istraživanjima. Svrha istraživanja nije samo objasniti ili razumjeti pedagoške situacije i pojave, nego ih i učiniti pravednijim, dovesti do promjene i emancipacije pojedinca i skupine. U okviru kritičke teorije realnost se smatra proizvodom koji je oblikovan djelovanjem različitih socijalnih, političkih, kulturalnih, ekonomskih, etničkih i rodnih čimbenika. Prema epistemološkom aspektu, u kritičkoj teoriji istraživači i predmet njihova istraživanja nisu razdvojeni, nego su međusobno usko povezani. Metodologija je dijaloška i dijalektička, a to znači da istraživači i subjekti istraživanja vode dijalog koji mora biti dijalektički da bi se prevladalo nekritičko mišljenje da su povijesno stvorene društvene strukture stalne i nepromjenjive. ${ }^{19}$ Kritički teoretičari važno mjesto daju povijesnim analizama zbog teorijskog mišljenja da je trenutno društveno stanje povijesno uvjetovano. Isto tako, kritički teoretičari intervjuiraju subjekte istraživanja te promatraju uvjete $\mathrm{u}$ kojima žive, poslove kojima se bave i druge aktivnosti u kojima sudjeluju.

Sudjelujuća paradigma je karakteristična za istraživanja u kojima se simultano ili sukcesivno kombiniraju kvalitativne i kvantitativne istraživačke metode. Predstavnici ove paradigme smatraju da postoji iskonska stvarnost - kozmos u kojemu um aktivno sudjeluje. Pri tome su svi dijelovi kozmosa u kojemu živimo međusobno isprepleteni i povezani, a ta povezanost nije mehanička, nego sudjelujuća. Odnosno, svi dijelovi te cjeline su u međusobnoj

\footnotetext{
${ }^{15}$ Usp. I. LAKATOS, Historija nauke i njezine racionalne rekonstrukcije, u: N. SESARDIĆ (ur.), Filozofija nauke, Beograd, Nolit, 1985, 266-312, 278.

${ }^{16}$ Usp. Bognar, Pedagogija na putu prema pluralizmu..., 102.

${ }^{17}$ Usp. isto.

${ }^{18}$ Usp. Bognar, Pedagogija na putu prema pluralizmu..., 103.

${ }^{19}$ Usp. isto, 104.
} 
interakciji i sudjelovanju. ${ }^{20}$ Ova paradigma podrazumijeva proširenu epistemologiju koja uključuje iskustveno, praktično, prezentacijsko i propozicijsko znanje. Iskustveno znanje nastaje na temelju suočavanja s drugim ljudima, mjestima ili stvarima. Praktično znanje je znanje o tome kako nešto učiniti i može se prepoznati kao vještina ili umijeće. Propozicijsko se znanje izražava u obliku tvrdnji i teorija. Prezentacijskim znanjem moguće je izraziti neverbalno iskustvo u nekoj umjetničkoj formi: ples, glazba, slika, crtež, poezija, drama ili priča. ${ }^{21}$ To je znanje premosnica između iskustvenoga i propozicijskog znanja. ${ }^{22}$ Metodologija se oslanja na proširenu epistemologiju u tom smislu da se istraživanje ostvaruje kao suradnički proces u kojemu sudjeluju svi zainteresirani subjekti i time se istraživanje ne provodi na drugim ljudima već s njima. ${ }^{23}$

Za današnja istraživanja možemo reći da teže interdisciplinarnom istraživačkome razvojnome trendu ${ }^{24}$ koji doprinosi provođenju vrhunskih istraživanja. Drugim riječima, proučavani fenomen se nastoji istražiti sa što više sadržajnih aspekata (pogled iz sfere različitih znanosti na isti problem) uključujući što više istraživačkih alata koji pripadaju i kvalitativnoj i kvantitativnoj metodologiji. U novije vrijeme informacijska tehnologija pomiče granice istraživanja i ima veliku ulogu u istraživanjima. ${ }^{25}$ Uloga znanstvenih paradigmi je olakšati istraživačima i usmjeriti njihov istraživački kontekst u okviru nekog filozofskog i metodološkog okvira, ali i otvoriti nove pristupe istraživanjima (futurološke metode) u okvirima postojećih paradigmi.

\section{Vrste istraživanja}

Pored znanstvenih paradigmi, vrste istraživanja nam također mogu pomoći da na što uspješniji način prepoznamo metodološki okvir kojega najčešće koriste budući učitelji. Pod utjecajem razvoja društvenih znanosti došlo je do povećanja novih taksonomija istraživanja odgoja i obrazovanja. Svaki od načina na koji se dijeli sustav pedagogije ujedno može biti i kriterij za razlikovanje vrste istraživanja odgoja i obrazovanja. Dioba istraživanja odgoja i obrazovanja koja ih sve najpotpunije obuhvaća jest ona koja razlikuje tri skupine: temeljna, primijenjena i razvojna istraživanja u koja se ubrajaju i akcijska istraživanja. ${ }^{26}$

\footnotetext{
${ }^{20}$ Usp. Bognar, Pedagogija na putu prema pluralizmu..., 105.

${ }^{21}$ Usp. isto.

${ }^{22}$ Usp. J. HERON, Philosophical basis for a new paradigm, u: P. REASON, J. ROWAN (ur.), Human inquiry. A sourcebook of new paradigm research, Toronto, John Wiley \& Sons, 1981, 19-35, 19.

${ }^{23}$ Usp. J. REASON, Participation in human inquiry, London, Thousand Oaks, New Delhi, SAGE Publications, 1994, 10.

${ }^{24}$ Usp. L. COHEN, L. MANION, K. MORRISON, Metode istraživanja u obrazovanju, Zagreb, Naklada Slap, 2007, 383.

${ }^{25}$ Usp. isto.

${ }^{26}$ Usp. Mužić, nav. dj., 27.
} 
Temeljnim se istraživanjima postižu nove spoznaje koje imaju znanstvenu vrijednost i doprinose ukupnoj sumi znanja u tom području. Ne očekuje se da takva istraživanja budu od neposredne praktične koristi te ne služe izravnoj primjeni u odgojno-obrazovnoj praksi nego se najčešće povezuju s temeljnima iz drugih znanosti putem čega se u njima ostvaruje interdisciplinarni pristup. Cilj je proširivanje postojećeg znanja o pedagoškim pojavama. Međutim, istraživački problemi takvih istraživanja mogu biti i problemi empirijske prirode. Temeljna se istraživanja bave svim problemima pedagogije kao znanosti, a to su: aksiološka pitanja pedagogije, pitanja predmeta proučavanja pedagogije, etička pitanja pedagogije, epistemološko-metodološka pitanja te pitanja jezika pedagogije. $^{27}$

Primijenjeno istraživanje služi stjecanju znanja i spoznaja nužnih za rješavanje nekog neposrednog praktičnog problema. U procesu odgoja i obrazovanja se to odnosi na unapređivanje te djelatnosti na nekom njezinom području. Bave se provjerom teorija ili stvaranjem novih hipoteza i teorija, na temeljnu empirijski prikupljenih podataka. Zato su takva istraživanja najčešće empirijska, ali ih ima i neempirijskih. Primijenjena se istraživanja temelje na sintezi kvantitativnog i kvalitativnog pristupa, a njima se obično prikazuje napredak temeljnih istraživanja. Odnosno, primijenjena istraživanja imaju zadatak operacionalizacije pedagoških spoznaja iz temeljnih istraživanja. ${ }^{28}$

Razvojna istraživanja proučavaju procese razvoja pedagoških fenomena u funkciji vremena i to na temelju znanstvenoga istraživanja s jedne i praktičnoga iskustva s druge strane. Za razvojna je istraživanja važno da uvijek postoji i znanstveno utemeljena terenska provjera. Akcijska istraživanja svrstavamo u razvojna istraživanja, jer se ona odnose na proces traganja za novim spoznajama putem mijenjanja ili razvijanja postojeće pedagoške prakse. ${ }^{29}$ Primjena akcijskih istraživanja u odgoju i obrazovanju doprinosi povezivanju prakse i teorije te rješavanju svakodnevnih problema praktičara. U njegovoj realizaciji sudjeluju oni koji su neposredni sudionici te situacije radi unapređivanja prakse i kvalitete njenog razumijevanja. U školi koja je usmjerena na promjene učitelji više ne mogu biti samo predavači i korisnici rezultata drugih istraživanja, nego trebaju postati aktivni refleksivni sudionici u procesu istraživanja. ${ }^{30}$ Akcijskim se istraživanjima osnažuju pojedinci i društvene skupine da preuzmu kontrolu nad svojim životima u okviru promicanja, a ne potiskivanja općih interesa. ${ }^{31}$

Sve se navedene vrste istraživanja mogu shvatiti kao na činjenicama zasnovan, temeljan, objektivan, sistematičan, kontroliran te planiran proces stjecanja znanja nužnih za identifikaciju i rješavanje problema u odgojno-obrazovnoj

\footnotetext{
${ }^{27}$ Usp. O. KNEŽEVIĆ FLORIĆ, S. NINKOVIĆ, Horizonti istraživanja, Novi Sad, Filozofski fakultet, 2012, 76.

${ }^{28}$ Usp. Mužić, nav. dj., 28.

${ }^{29}$ Usp. isto, 29.

${ }^{30}$ Usp. B. BOGNAR, Akcijska istraživanja u školi, Odgojne znanosti, 8 (2006) 1, 209-227, 209.

${ }^{31}$ Usp. Cohen, Manion, Morrison, nav. dj., 383.
} 
djelatnosti. Stoga je i svako od tih istraživanja važno, kako za proširivanje teorije pomoću rezultata temeljnih istraživanja, tako i za unapređivanje prakse razvojnim i akcijskim istraživanjima.

U ovomu ćemo se radu voditi Mužićevom podjelom na navedene vrste istraživanja te nećemo ulaziti u dublje analize koje se odnose na vrste prema vremenu (istraživanje prošlosti, sadašnjosti i budućnosti) i trajanju (longitudinalna i transverzalna) istraživanja. ${ }^{32}$

\section{Ciljevi i zadaće istraživanja}

Ciljevi i zadaće istraživanja odnose se na istraživanje obranjenih diplomskih radova studenata učiteljskoga studija te prepoznavanje različitih istraživačkih pristupa i metodoloških okvira $u$ istraživanjima (diplomskim radovima) budućih učitelja koji se ogledaju u zastupljenosti znanstvenih paradigmi, postojanju kvalitativne i kvantitativne metodologije te različitih istraživačkih metoda kojima se u svojim istraživanjima koriste budući učitelji. Pored navedenoga, istraživanjem smo željeli istražiti i zastupljenost pojedinih znanstvenih područja i polja u diplomskim radovima. Dobiveni rezultati će nam pomoći pri transformiranju teorija i pravila ostvarujući nove iskorake $u$ istraživanjima odgoja i obrazovanja (posebno u pedagogiji), a koje nam mogu pomoći u stvaranju nove paradigme.

U istraživanju su postavljena sljedeća istraživačka pitanja (specificirani istraživački ciljevi):

1. Koliko diplomskih radova obuhvaća istraživanje?

2. Koje je najzastupljenije znanstveno područje u diplomskim radovima?

3. Koje je najzastupljenije znanstveno polje u diplomskim radovima?

4. Kolika je zastupljenost pojedinih znanstvenih paradigmi u diplomskim radovima?

5. Koje vrste istraživanja studenti koriste u diplomskim radovima?

6. Koje su istraživačke metode zastupljene u diplomskim radovima?

\section{Metodologija i uzorak istraživanja}

Istraživanje je provedeno metodom rada na dokumentaciji u okviru koje se proučavalo 159 diplomskih radova studenata Učiteljskoga studija Fakulteta za odgojne i obrazovne znanosti u Sveučilišta Osijeku koji su javno obranjeni od siječnja 2015. do prosinca 2017. godine. ${ }^{33}$

\footnotetext{
${ }^{32}$ Usp. Mužić, nav. dj., 31.

${ }^{33}$ Navedenim je diplomskim radovima moguće pristupiti na stranicama Repozitorija Fakulteta za odgojne i obrazovne znanosti Sveučilišta u Osijeku, https://repozitorij.foozos.hr.
} 


\section{Metoda i provedba istraživanja}

Metoda koja je korištena u ovom istraživanju jest analiza sadržaja cjelokupnoga diplomskog rada. S obzirom na velik broj diplomskih radova (159), s prosječnih 40 stranica po radu, prije provedene analize ujednačeni su kriteriji prema kojima se radila analiza: ima li rad istraživanje ili nema, razvrstavanje rada prema pripadnosti uočenome znanstvenome području i polju, ispis svih istraživačkih metoda i njihovo naknadno razvrstavanje pripadnosti nekoj znanstvenoj paradigmi te uočavanje vrste istraživanja u odnosu na njezinu primjenu u praksi. Podatci su se upisivali u ujednačene tablice radi lakšega snalaženja i prikazivanja podataka.

$\mathrm{S}$ obzirom na brojnost i veličinu diplomskih radova, analiza se provodila $\mathrm{u}$ trajanju od tri godine (2015.-2017.).

\section{Rezultati istraživanja i interpretacija}

Rezultati istraživanja pokazuju da 83 \% diplomskih radova ima istraživanje te se time odgovorilo na prvo istraživačko pitanje (Koliko diplomskih radova ima istraživanje?). Rezultati su vidljivi u grafikonu 1.

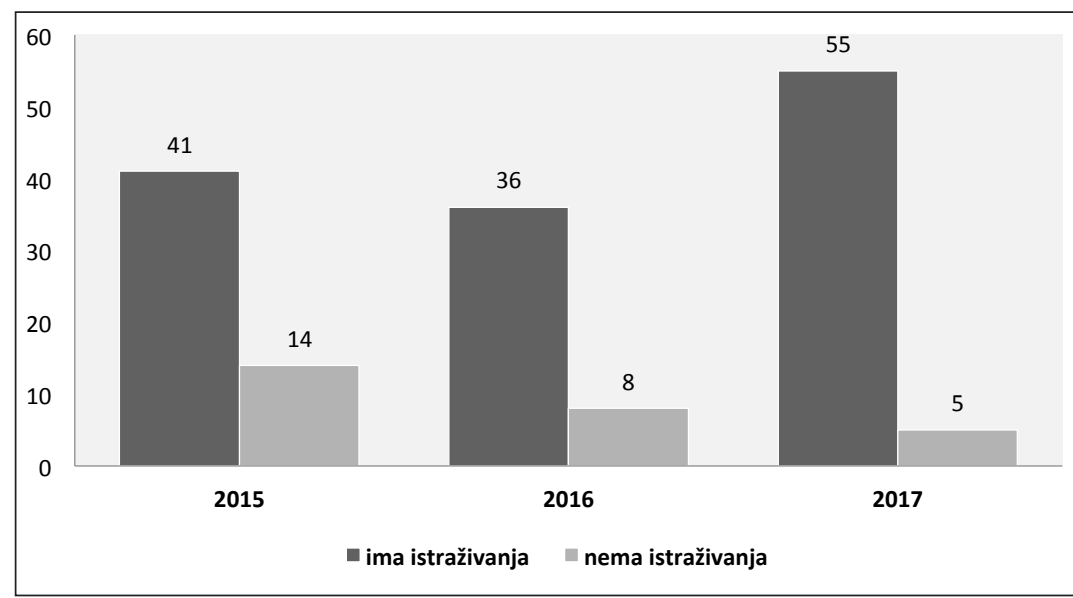

Grafikon 1. Zastupljenost istraživanja u diplomskim radovima studenata Učiteljskoga studija

Potom smo istražili zastupljenost pojedinoga znanstvenog područja u diplomskim radovima te analizirali odnos između znanstvenoga područja i provođenja ili neprovođenja istraživanja, odnosno, uz ovaj smo zadatak istražili i kolika je zastupljenost provođenja istraživanja s obzirom na pojedino znanstveno područje diplomskoga rada. Rezultati istraživanja prikazani su u tablici 1. 
Tablica 1. Zastupljenost znanstvenih područja u istraživanjima budućih učitelja.

\begin{tabular}{|c|c|c|c|c|c|c|c|c|}
\hline \multirow{2}{*}{$\begin{array}{c}\text { ZNANSTVENO } \\
\text { PODRUČJE }\end{array}$} & \multicolumn{2}{|c|}{$\mathbf{2 0 1 5 .}$} & \multicolumn{2}{c|}{$\mathbf{2 0 1 6 .}$} & \multicolumn{2}{c|}{$\mathbf{2 0 1 7 .}$} & \multicolumn{2}{c|}{ Ukupno } \\
\cline { 2 - 9 } & $\mathbf{f}$ & $\mathbf{\%}$ & $\mathbf{f}$ & $\mathbf{\%}$ & $\mathbf{f}$ & $\mathbf{\%}$ & $\mathbf{f}$ & $\mathbf{\%}$ \\
\hline Društvene znanosti & 27 & 46,55 & 17 & 29,31 & 14 & 24,14 & 58 & 36,47 \\
\hline Prirodne znanosti & 13 & 32,50 & 13 & 32,50 & 14 & 35 & 40 & 25,16 \\
\hline Umjetničko područje & 10 & 26,32 & 8 & 21,06 & 20 & 52,62 & 38 & 23,90 \\
\hline Humanističke znanosti & 5 & 21,74 & 6 & 26,09 & 12 & 52,17 & 23 & 14,47 \\
\hline Ukupno & 55 & & 44 & & 60 & & 159 & 100 \\
\hline
\end{tabular}

Odgovor na postavljeno istraživačko pitanje (Koje je najzastupljenije znanstveno područje u diplomskim radovima?), jest da je znanstveno područje društvenih znanosti najzastupljenije među diplomskim radovima od 36,47 \%, slijede ga prirodne znanosti sa $25,16 \%$, potom umjetničko područje sa $23,9 \%$ te najmanju zastupljenost pokazuju humanističke znanosti sa svega 14,47 \% diplomskih radova. Ostala se znanstvena područja ne pojavljuju u ovom dijelu promatrane dokumentacije.

S obzirom na to da su podaci prikupljeni na Fakultetu za odgojne i obrazovne znanosti (Osijek) i cjelokupan plan i program njegova poučavanja budućih učitelja, razumljivo je da se studenti u najčešće odlučuju za pisanje diplomskih radova s područja društvenih znanosti jer su kolegiji pedagogije, psihologije, interdisciplinarnih društvenih znanosti, edukacijsko-rehabilitacijskih znanosti i drugi s ovoga područja zastupljeni od prve do zadnje godine studija, imaju mnoge profesore koji ih provode i koji su kasnije mentori za pisanje diplomskih radova iz svojih znanstvenih područja.

S obzirom na to da je najviše diplomskih radova obuhvatilo upravo ovo područje, odlučili smo istražiti i zastupljenost prije navedenih znanstvenih polja (grafikon 2.).

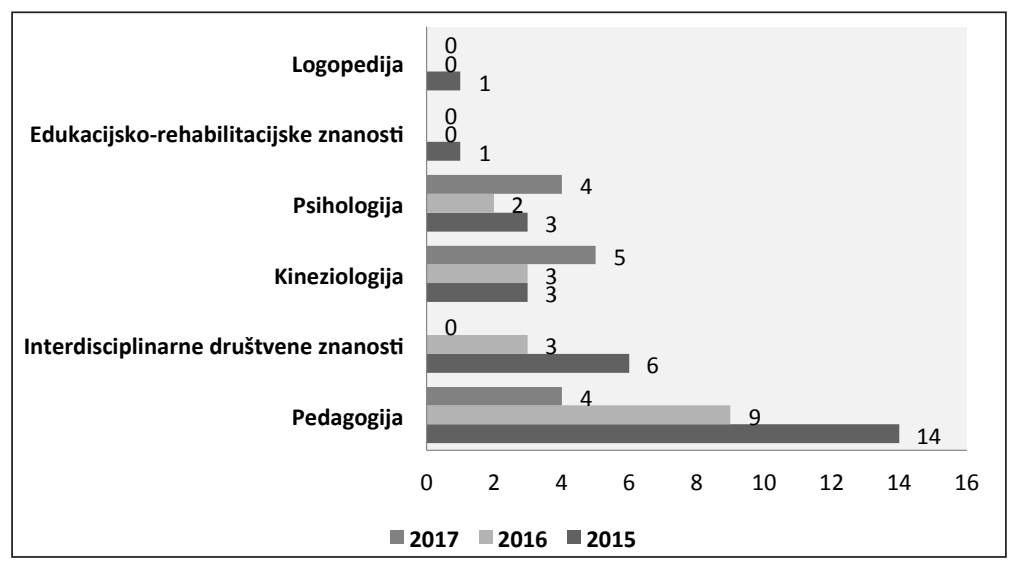

Grafikon 2. Zastupljenost znanstvenih polja društvenoga područja u diplomskim radovima studenata učiteljskoga studija. 
Diplomski radovi iz područja društvenih znanosti u promatranoj dokumentaciji uključuju znanstvena polja pedagogije, psihologije, kineziologije, interdisciplinarne društvene znanosti, edukacijsko-rehabilitacijske znanosti i logopedije. Grafikon 2. nam prikazuje da među njima prevladava pedagogija. Odgovor na postavljeno istraživačko pitanje (Koje je najzastupljenije znanstveno polje u diplomskim radovima?), jest postotak od $46,55 \%$ u korist pedagogije, što je iznimno važan podatak s obzirom na to da odgajamo i obrazujemo buduće učitelje kojima će pedagoško djelovanje biti svakodnevica.

Analizirajući filozofski pristup, teorijsku podlogu, brojnost, vrstu i zastupljenost pojedinih istraživačkih metoda, mogli smo odrediti kojoj od navedenih pet paradigmi o kojima je pisao Bognar ${ }^{34}$ pripada svaki pojedini diplomski rad. Grafikon 3. prikazuje tu analizu.

Rezultati istraživanja pokazuju da studenti (u diplomskim radovima u kojima ima istraživanje) najčešće (60,6 \%) istražuju u području pozitivističke paradigme i da su se koristili uglavnom jednim istraživačkim instrumentom, kvantitativnom metodologijom.

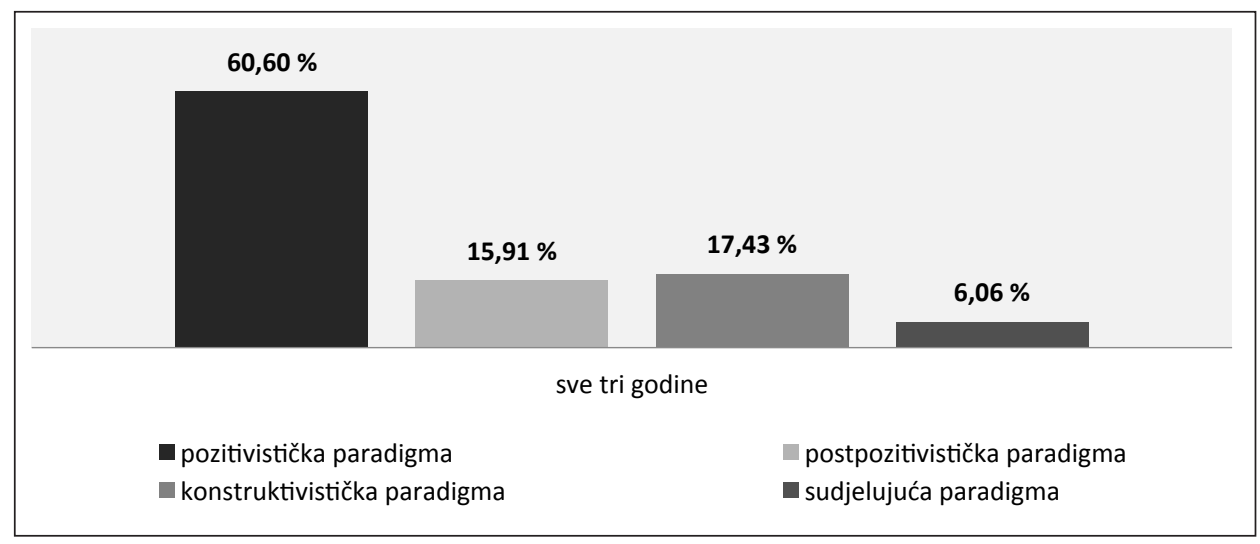

Grafikon 3. Zastupljenost znanstvenih paradigmi u diplomskim radovima studenata učiteljskoga studija.

Zastupljenost konstruktivističke (17,43\%) i postpozitivističke paradigme $(15,91 \%)$ je podjednaka, a navedeni rezultati čine odmak od potpune kvantifikacije dobivenih rezultata i malo veću uključenost istraživača u samo istraživanje. Time smo dobili odgovor na sljedeće istraživačko pitanje (Kolika je zastupljenost pojedinih znanstvenih paradigmi u diplomskim radovima?). Znanstvena paradigma kritičke teorije je potpuno izostala pa smo je uklonili iz grafikona 3. radi bolje preglednosti.

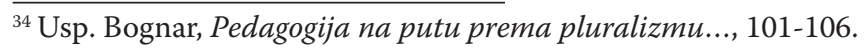


Grafikon 4. prikazuje zastupljenost pojedinih vrsta istraživanja u diplomskim radovima (2015.-2017.) prema kriterijima: temeljnih, primijenjenih i razvojnih istraživanja (u koja samo uvrstili i akcijska istraživanja).

Iz grafikona 4. možemo uočiti da dominiraju primijenjena istraživanja (78 \%), dok su razvojna istraživanja (5 \%) još uvijek nedovoljno korištena od strane studenata, ali i njihovih mentora. S obzirom da su u našu analizu ušli samo diplomski radovi, može se pretpostaviti je da se studenti pri završetku studija češće odlučuju za one istraživačke metode koje im neće oduzeti puno vremena, kao što se to obično očekuje u akcijskim istraživanjima.

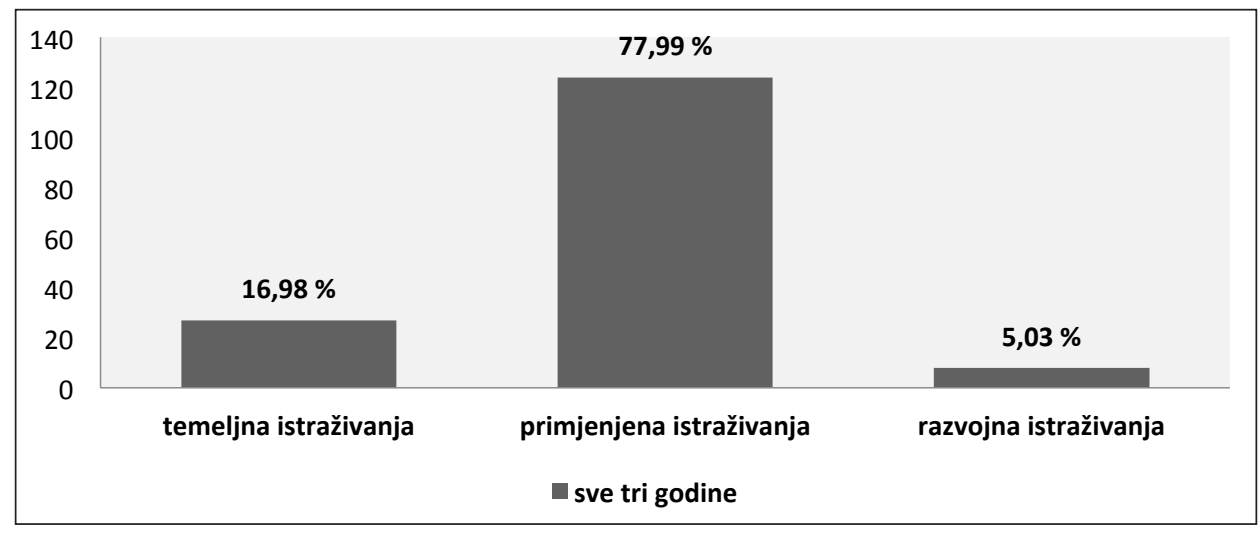

Grafikon 4. Zastupljenost vrsta istraživanja u diplomskim radovima studenata učiteljskoga studija.

Grafikon 4. ujedno i daje odgovor na sljedeće istraživačko pitanje (Koje vrste istraživanja studenti koriste u diplomskim radovima?). S obzirom da primijenjena istraživanja služe stjecanju znanja i spoznaja nužnih za rješavanje nekog neposrednog praktičnog problema, bilo je očekivano da će budući učitelji istraživati nešto čije će rezultate moći primijeniti u svome budućemu poslu. Pored navedenoga, pretpostavljamo da su i neke od ideja za istraživanje studenti dobili boraveći na praksi tijekom pet godina studija.

Posljednje što smo istražili bila je zastupljenost pojedinih istraživačkih metoda. Grafikon 5. daje uvid u dobivene rezultate istraživanja.

Od 132 diplomska rada koja su imala istraživanja u razdoblju od 2015. do 2017. godine, njih čak 60,6 \% je koristilo samo jednu istraživačku metodu - anketu. Smatramo da se anketiranje zbog svoje jednostavnosti u dijelu pripreme, provedbe, obrade te osigurane anonimnosti, najčešće provodi, ali i zbog najmanje uključenosti samoga istraživača $u$ istraživanje (anketirati čak ne mora ni sam istraživač, a danas znamo da su popularne on-line ankete). Navedeni podatci se poklapaju s prisutnošću pozitivističke paradigme $u$ jednakom postotku $(60,6 \%)$. Ovim smo uvidom u istraživane diplomske radove dobili odgovor i 


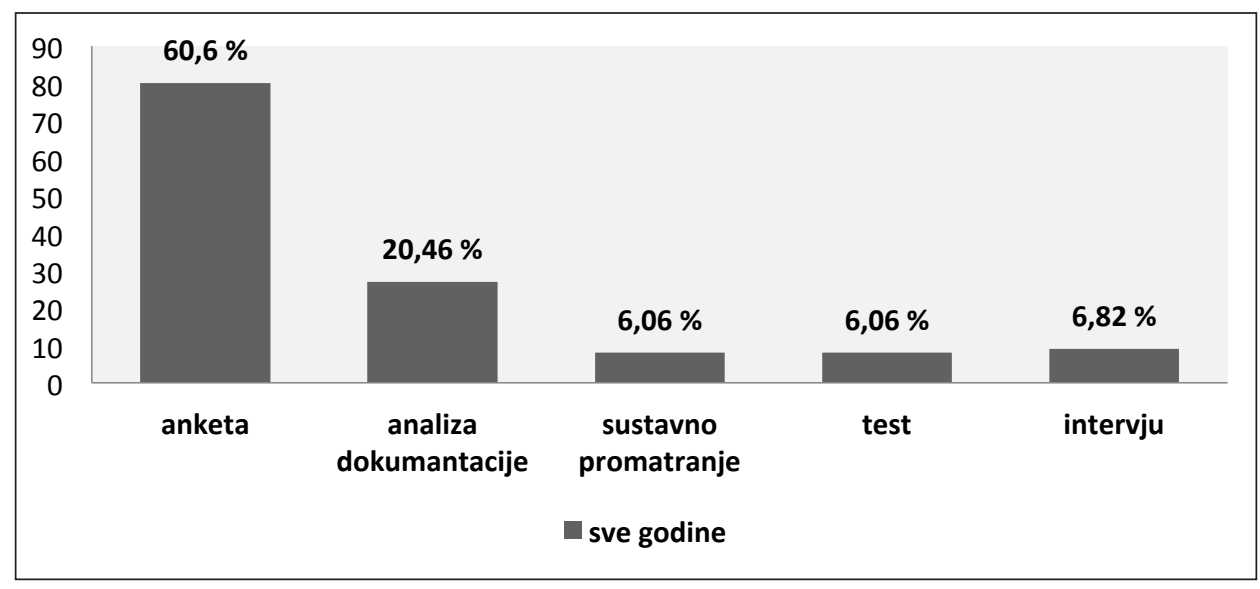

Grafikon 5. Zastupljenost istraživačkih metoda u diplomskim radovima studenata učiteljskoga studija.

na posljednje istraživačko pitanje (Koje su istraživačke metode zastupljene u diplomskim radovima?).

\section{Rasprava}

Rezultati istraživanja pokazuju da se u razdoblju od tri godine (2015.-2017.) broj diplomskih radova koji nema istraživanje smanjuje te ih je u 2017. godini obranjeno samo 5 . Iz ovoga možemo zaključiti da su novije generacije studenata sklonije istraživanju u diplomskim radovima, a tome sigurno doprinosi i sve veća upotreba informacijske tehnologije koja olakšava pristup sudionicima istraživanja i raznim obradama podataka. Nadalje, najzastupljenije znanstveno područje u okviru kojega studenti istražuju su društvene znanosti (36,47 \%), što se moglo i očekivati jer je riječ o budućim učiteljima. Pedagogija se u visokome postotku (46,55 \%) pokazala kao najzastupljenije znanstveno polje koje studenti rado odabiru jer se u okviru njega mogu baviti temama s kojima će se najčešće susretati u svome budućemu poslu, ali i stoga što studij obiluje obaveznim i izbornim pedagoškim kolegijima. Rezultatima doprinosi i podatak da je jedan od tri modula ${ }^{35}$ prema kojima se studenti odgajaju i obrazuju za magistra primarnoga obrazovanja na Fakultetu odgojnih i obrazovnih znanosti u Osijeku i tzv. Modul A - razvojni modul koji ima pojačane pedagoške kolegije. Rezul-

\footnotetext{
${ }^{35}$ Modul A - razvojni smjer izabranim predmetima iz pedagogije, psihologije i metodika šire osposobljava studente za razumijevanje specifičnih pitanja odgoja i obrazovanja te razvoja djeteta. Modul B - smjer informatike, studente temeljitije osposobljava za korištenje informacijskih tehnologija u odgojno-obrazovnom procesu, te za informatički odgoj i obrazovanje djece $u$ prva četiri razreda osnovne škole. Modul C - smjer strani jezik studente dodatno osposobljava za rano poučavanje djece mlađe školske dobi stranom jeziku.
} 
tati pokazuju i najveću zastupljenost pozitivističke paradigme (60,6 \%) koja je karakteristična za kvantitativna istraživanja. Epistemologija pozitivističke (pa i postpozitivističke) paradigme nastoji distancirati istraživače i predmete njihova istraživanja pa je svrha takvih istraživanja objektivna spoznaja stvarnosti na temelju empirijski prikupljenih podataka. Metode za koje se na takav način prikupljaju podatke omogućavaju precizno mjerenje, kvantifikaciju, testiranje hipoteza te kontrolu varijabli, a analiza tako prikupljenih podataka je statistička. To baš ne odgovara prirodi istraživanja u pedagogiji (46,55 \%) u kojoj se pedagoški fenomeni istražuju uglavnom u okviru kvalitativne metodologije. Ajduković također ističe važnost kvalitativne metodologije u istraživanjima, što se u našem kontekstu posebno odnosi na istraživanja u odgoju i obrazovanju. ${ }^{36}$ Prilikom istraživanja zastupljenosti istraživačkih metoda u diplomskim radovima, uočeno je da prevladava anketa $(60,6 \%)$, što je i bilo očekivano nakon rezultata o prevlasti pozitivističke paradigme. Studenti u nešto manjim postocima koriste analizu dokumentacije $(20,46 \%)$ i sustavno promatranje $(6,06 \%)$ jer te metode oduzimaju više vremena u svojoj pripremi i provedbi. Samo 6,82 $\%$ studenata koristi intervju za prikupljanje potrebnih podataka. Iako intervju smatramo najprirodnijim i najdostojanstvenijim načinom prikupljanja podataka, on zahtijeva najdužu pripremu, provedbu i kategorizaciju prikupljenih odgovora, što je vjerojatan razlog njegove rijetke upotrebe. S obzirom na vrstu istraživanja u vrlo visokom postotku se koriste primijenjena istraživanja (78 \%). To je svakako pozitivno jer istražujući neki problem kao istraživač želimo da se nakon našega istraživanja stanje promijeni ili da barem ukažemo na načine koji mogu doprinijeti promjeni postojećega stanja.

Provedeno nam istraživanje pokazuje da studenti češće koriste kvantitativne tehnike prikupljanja podataka, stoga se i većina obranjenih diplomskih radova studenata sastoji od teorijskoga i istraživačkoga dijela u kojemu je najčešća istraživačka tehnika kvantitativna (anketa). Razloge tomu možemo potražiti u jednostavnijoj (ponekad i odmah on-line dostupnoj) analizi tako prikupljenih podata$\mathrm{ka}$, ali i njihovome prikazu (kroz grafikone, histograme, tablice i slično). Kuhn je naglašavao da je prilikom istraživanja važno kontinuirano promatrati istraživane pojave $\mathrm{s}$ više gledišta, iako nam se neko gledište možda činilo i poznatim. ${ }^{37}$

Potrebno je da na sličan način pristupimo proučavanju metodologije i pronalaženju optimalnih istraživačkih metoda, pristupa i paradigmi vodeći se osobnim istraživačkim ciljevima. Djelomično, na dio rezultata su vjerojatno utjecali i mentori koji su možda studentima sugerirali istraživačke alate ili su im ponudili gotove instrumente te ih na taj način »usmjerili« prema stanovitoj znanstvenoj paradigmi.

\footnotetext{
${ }^{36}$ Usp. M. AJDUKOVIĆ, Kako izvještavati o kvalitativnim istraživanjima? Smjernice za istraživače, mentore i recenzente, Ljetopis socijalnog rada, 21 (2014) 3, 345-366.

${ }^{37}$ T. S. KUHN, The Structure of Scientific Revolutions, Chicago, IL, University of Chicago Press, ${ }^{3} 1996$.
} 


\section{Ograničenja istraživanja}

Zbog nepostojanja standardiziranog mjernog instrumenta i relativno malog broja diplomskih radova koji su ušli $u$ istraživanje $(\mathrm{N}=159)$ te neuključivanja diplomskih radova budućih učitelja s drugih učiteljskih fakulteta u Hrvatskoj, dobivene je podatke nemoguće generalizirati, ali su oni svakako vrijedni pokazatelji koje je važno uzeti u obzir za daljnja istraživanja ove problematike. Zbog velikog opsega diplomskih radova (svaki diplomski rad ima u prosjeku 40-ak stranica) nismo ulazili u dublje analize vrste istraživanja prema vremenu i trajanju, što također može biti preporuka za daljnja istraživanja.

\section{Pedagoške implikacije}

Pedagoške implikacije istraživanja mogu biti redefiniranje postojećega plana i programa te proširivanje satnice iz metodoloških kolegija za buduće učitelje u okviru kojih bi se studentima više naglašavala važnost primjene različitih istraživačkih metoda, posebno kvalitativnih, jer su rezultati ovoga istraživanja pokazali da je pedagogija najviše istraživano polje pri kojemu prevladavajuće metode istraživanja nisu bile kvantitativne nego kvalitativne. Nužno je kombinirati kvalitativnu i kvantitativnu metodologiju da bi se dobio cjelovit uvid i da bi se rezultate takvoga istraživanja moglo što uspješnije primijeniti u praksi. Važno je poticati pluralizam znanstvenih paradigmi u istraživanjima studenata te kao istraživač biti sudionikom istraživanja. Također, vidimo da su o ovim istraživanjima posve izostale manje poznate metode, kao npr. futurološke metode istraživanja o kojima je već pisala Dubovicki, ${ }^{38}$ a koje bi studentima koristile u istraživanjima odgoja i obrazovanja. Posljednja pedagoška implikacija odnosila bi se na mentore koji svojim sugestijama mogu pomoći uspješnijem istraživanju studenata.

\section{Zaključak}

Za učitelje je važno da budu uspješni praktičari, ali se isto tako od njih očekuje i da istražuju svoju odgojno-obrazovnu djelatnost. Često nam rezultati istraživanja pomažu da uočimo problem, osvijestimo ga, a potom i djelujemo na promjenu postojećega stanja u ono željeno. Dosadašnji rezultati istraživanja nam pokazuju da su budući učitelji još uvijek skloniji »detektiranju« problema (anketa 60,6 \%) negoli stvarnoj akciji (mijenjanju prakse/rješavanju problema),

\footnotetext{
${ }^{38}$ S. DUBOVICKI, Futurološke metode istraživanja, u: S. OPIĆ, B. BOGNAR, S. RATKOVIĆ (ur.), Novi pristupi metodologiji istraživanja odgoja, Zagreb, Učiteljski fakultet Sveučilišta u Zagrebu, 2017, 203-221.
} 
što je značajka razvojnih istraživanja kojih je u diplomskim radovima bilo samo $5 \%$. Nije poželjno provoditi samo jednu vrstu istraživanja ili koristiti samo jednu metodologiju. Znanstveno područje (društvene znanosti) i polje (pedagogija) koje se u ovom istraživanju pokazalo najzastupljenijim, od istraživača zahtijeva kombinaciju istraživačkih alata koji uključuju i kvalitativne i kvantitativne pokazatelje, jer pedagoška problematika često za teme istraživanja ima složenije izazove, kao što su npr: odgoj, kreativnost ili emocije, koje nije jednostavno »izmjeriti«, ali ni istražiti bez mnogovrsnih istraživačkih alata.

Znanstveni doprinos rada čini istraživanje kojim se željelo utvrditi »početno « stanje na temelju kojega će se u idućim godinama povećati istraživanja svih znanstvenih paradigmi te poticati studente da pri istraživanjima koriste različite istraživačke metode, pa i one koje su im nove (npr. futurološke) jer obogaćuju istraživanje i čine ga kvalitetnijim. Pluralizam paradigmi kao i upotreba i kvalitativne i kvantitativne metodologije, različite vrste istraživanja te metode prikupljanja podataka - važne su da bi se istražila slojevitost odgojno-obrazovnoga procesa na svim njegovim razinama i sa što više aspekata te unaprijedila njegova učinkovitost. 


\section{Snježana Dubovicki" - Vesnica Mlinarevićn - Tena Velki" \\ Research Approaches and Methodological Framework in the Research of Future Teachers}

\section{Summary}

More recently, in social sciences, especially in pedagogy, different research experiences imply different research styles and philosophical approaches that need to be known before conducting research. This paper gives an overview of different research approaches and scientific paradigms within which it is possible to create and direct a personal research project (or research). The aim and purpose of the paper is to explore various research approaches and methodological frameworks that are reflected in the representation of certain scientific paradigms, the presence of qualitative and quantitative methodology and various research techniques used by future teachers in their research. For this reason, 159 graduate theses of students of teacher study, which were publicly defended from January 2015 to December 2017, were explored. Insight into students' graduate theses gives the following results: out of the total number of graduate papers (159), 132 (83\%) has a research part. Furthermore, the scientific field predominantly used in the research is social science (36.47\%), and within it the field of pedagogy (46.55\%). According to the type of research, dominant are empirical, fundamental, transversal and research of the present. Of all the research paradigms investigated, the most prominent is the positivist (60.6\%), and then the constructivist (17.43\%) and post-positivist (15.91\%) paradigm. Applied research dominate (78\%), while development research (5\%) is still insufficiently represented and recognized by students.

Key words: graduate theses, students of teacher study, types of research, scientific paradigms.

(na engl. prev. Ružica Tokić)

* Snježana Dubovicki, PhD, Assis. Prof., Faculty of Education, Josip Juraj Strossmayer University of Osijek, Address: Cara Hadrijana 2, HR-31000 Osijek, Croatia; E-mail: sdubovicki@ gmail.com.

** Vesnica Mlinarević, PhD, Full Prof., Faculty of Education, Josip Juraj Strossmayer University of Osijek, Address: Cara Hadrijana 2, HR-31000 Osijek, Croatia; E-mail:vmlinarevic@foozos. hr.

**** Tena Velki, PhD, Assoc. Prof., Faculty of Education, Josip Juraj Strossmayer University of Osijek, Address: Cara Hadrijana 2, HR-31000 Osijek, Croatia; E-mail: tvelki@gmail.com. 